\title{
The Cell Cycle of the Budding Yeast Sterigmatomyces halophilus: Levels of Mitochondrial Components in Mother and Bud Cells
}

\author{
By IAN SALMON† AND ROBERT K. POOLE* \\ Department of Microbiology, Queen Elizabeth College, University of London, Campden Hill, \\ London W8 7 AH, U.K.
}

(Received 21 September 1982; revised 29 December 1982)

\begin{abstract}
Sterigmatomyces halophilus is an unusual budding yeast in which daughter cells are formed remote from the mother cell on fragile projections called sterigmata. These sterigmata are readily disrupted by ultrasonication, allowing easy detachment of immature buds from their mother cells. Fractions containing cells at different stages of the cell cycle, obtained by isopycnic fractionation of exponentially growing cultures, were treated ultrasonically to produce a mixture of immature buds, mothers and mother-bud doublets. Rate-sedimentation of these suspensions using sucrose gradients produced three discrete bands corresponding to each of these populations. The activities of succinate dehydrogenase and cytochrome $c$ oxidase were measured in extracts prepared from (1) the cells recovered from the slowest sedimenting band (i.e. immature buds) and (2) the original population (i.e. mother-bud doublets). The activity of each enzyme, expressed on a per cell basis, varied in phase with the observed activity in the mother-bud doublets during the cell cycle, and when expressed as specific activity was the same in both daughter and mother-daughter pairs. This indicates that these two enzymes (and by implication inner mitochondrial membrane) are evenly distributed between mother and developing daughter cells during the cell cycle.
\end{abstract}

\section{INTRODUCTION}

The cell cycle is a temporally and spatially ordered sequence of events in which the entire constituents of a cell are duplicated and ultimately segregated at division (for a survey, see Lloyd et al., 1982). In cells that divide by binary fission, cell separation is effected by the formation of a septum or cross wall in the mid-region of the cell, and results in the approximately equal distribution of cellular material between the two neonatal cells. In certain micro-organisms, notably the budding and prosthecate bacteria (Whittenbury \& Dow, 1977) and budding yeasts, development during the cell cycle is polarized in the sense that a morphologically distinct daughter cell is formed on the surface of an extant cell. Studies of wall development during the yeast cell cycle have shown that the incorporation of glucose (Johnson \& Gibson, 1966; Johnson, 1968), and of mannan (Farkas et al., 1974), is restricted to the bud wall, as is the secretion of acid phosphatase, the spatial organization of which requires the $c d c 24$ gene product (Field \& Schekman, 1980). An affinity cytochemical study by Skutelsky \& Bayer (1979) has shown that sites on the yeast surface are stationary and are not transferred to the newly synthesized bud wall. However, little is known of the development and localization of intracellular organelles and constituents during bud development, largely due to the problems in separating mother and bud cells for biochemical analysis. Galdiero (1973) studied the partitioning of total protein and lipid during the cell cycle of Saccharomyces cerevisiae by treating radioactively labelled cells from a synchronous culture in a Waring blender to detach the immature buds, which were then removed by differential centrifugation for analysis. The distribution of radioactivity indicated

† Present address: Biological Laboratory, The University, Canterbury, Kent CT2 7NJ, U.K. 
that both proteins and lipids were uniformly distributed between mother and bud cells throughout the cell cycle.

We have selected the budding yeast Sterigmatomyces halophilus for extending these observations, since the presumed fragility of the stalks or sterigmata connecting the buds to the mother cells (Fell, 1966) should allow considerably higher yields of immature buds to be obtained than was possible in the work of Galdiero (1973). In this paper, we exploit the characterization of the cell cycle of $S$. halophilus reported previously (Salmon \& Poole, 1983a,b) to study the distribution of marker enzymes for mitochondria between mothers and buds in the cell cycle. We report that the specific activities of two such enzymes are equal in mothers and buds throughout the cycle, and that the (uncharacterized) mechanisms that generate oscillatory changes in activity during the cycle are expressed synchronously in both cell types.

Parts of this work have been presented previously in abstract form (Salmon \& Poole, 1980a).

\section{METHODS}

Maintenance and growth of the organism. Sterigmatomyces halophilus CBS 4609 was maintained on a solid, complex medium and grown in a defined liquid medium with glucose as the growth-limiting substrate as described previously (Salmon \& Poole, $1980 \mathrm{~b}$ ).

Harvesting and culture fractionation. Exponentially growing cultures were harvested by passing the culture through an MSE continuous action rotor and resuspending the cells in a small volume of $3 \%(\mathrm{w} / \mathrm{v}) \mathrm{NaCl}$ (Salmon \& Poole, 1983a). Fractionation of the cell population into various size classes, representing successive stages in the cell cycle, was by isopycnic-zonal centrifugation through Urografin gradients (Salmon \& Poole, 1983a). Fractions were collected, and the cells harvested and washed as described previously (Salmon \& Poole, 1983a) and resuspended in $50 \mathrm{~mm}$-Tris/ $\mathrm{H}_{2} \mathrm{SO}_{4}$ buffer ( $\mathrm{pH} 7 \cdot 2$ ).

Disruption of sterigmata and the isolation of immature daughters. To disrupt sterigmata, samples ( 1 to $2 \mathrm{ml})$ were treated ultrasonically for $60 \mathrm{~s}$ ( $6 \mu \mathrm{m}$ peak to peak) using a titanium probe (end diameter $3.2 \mathrm{~mm}$ ) of an MSE $100 \mathrm{~W}$ Ultrasonic Disintegrator. Temperature rises were prevented by surrounding the samples with an ice-bath, and by carrying out the sonication in two $30 \mathrm{~s}$ periods separated by a $30 \mathrm{~s}$ period of cooling.

To isolate immature daughter cells (i.e. buds), samples containing cells at different stages in the cell cycle were sonicated. The resulting suspension, containing a mixture of immature buds, mother cells and mother-daughter pairs, was loaded on to a 10 to $40 \%(\mathrm{w} / \mathrm{w})$ sucrose gradient of $10 \mathrm{mI}$ total volume. These gradients were linear with respect to volume and contained $3 \%(\mathrm{w} / \mathrm{v}) \mathrm{NaCl}$ throughout. Centrifugation was at various speeds and lengths of time depending upon the original suspension (see Results). After centrifugation, the suspension was separated into two or more bands (see Results), the upper of which was removed with a fine needle and the particles washed as described previously (Salmon \& Poole, 1983a) and finally resuspended in $50 \mathrm{mM}-\mathrm{Tris} / \mathrm{H}_{2} \mathrm{SO}_{4}$ buffer $(\mathrm{pH} 7 \cdot 2)$.

Preparation of cell-free extracts and enzyme assays. Cells were broken by two slow passages through a cold French pressure cell at $138 \mathrm{MPa}\left(20000 \mathrm{lbf} \mathrm{in}^{-2}\right)$, and the unbroken cells and cell wall debris removed by centrifugation to yield the cell-free extract (Salmon \& Poole, 1983b). Cytochrome $c$ oxidase and succinate dehydrogenase were assayed in these extracts using the procedures of Salmon \& Poole (1983b).

Protein assays. The total protein of whole cells was determined as described by Salmon \& Poole (1983a). Protein in cell-free extracts was assayed using Lowry's method with corrections for Tris interference (Salmon \& Poole, $1983 \mathrm{~b}$ ). BSA was the standard in both cases.

Cell numbers and volumes. These were determined using a Coulter Counter Model $Z_{\mathrm{BI}}$ as described by Salmon \& Poole (1983a).

Chemicals. Sucrose of analytical grade was obtained from Fisons, and Urografin 370 from Schering Chemicals, Burgess Hill, RH15 9NE, U.K. Cytochrome $c$ (type III, from horse heart) and 2,6-dichlorophenolindophenol were from Sigma, and phenazine methosulphate was from Koch-Light. BSA was from Armour Pharmaceuticals, Eastbourne, U.K.

\section{RESULTS}

\section{Effect of ultrasonication on $S$. halophilus from an exponentially growing culture}

The changes in cell numbers, mean cell volume and total cell volume in a sample of $S$. halophilus from an exponentially growing culture, ultrasonicated for different lengths of time, are shown in Fig. 1. Cell numbers increased by approximately $36 \%$ during the first $20 \mathrm{~s}$ of sonication, and then remained constant. The mean cell volume showed a correspondingly rapid decrease from 19.4 to $14.3 \mu \mathrm{m}^{3}$ during this period, followed by a much slower decrease to $13.6 \mu \mathrm{m}^{3}$ by $60 \mathrm{~s}$. This had the effect of maintaining the 'biovolume' or total cell volume (the 


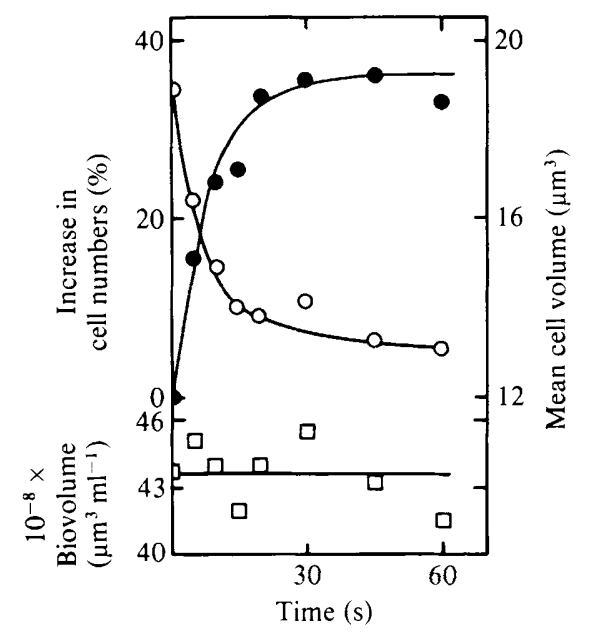

Fig. 1. The effect of ultrasonication on a suspension of $S$. halophilus. A titanium probe (end diameter $3.2 \mathrm{~mm}$ ) of a MSE $100 \mathrm{~W}$ Ultrasonic Disintegrator was introduced into $2 \mathrm{ml}$ of a suspension of $S$. halophilus $\left(2 \cdot 26 \times 10^{8}\right.$ cells $\left.\mathrm{ml}^{-1}\right)$. The suspension was then sonicated for increasing periods of time. Samples $(20 \mu 1)$ were removed at intervals for counting and sizing. The percentage increase in cell numbers $(\bigcirc)$, the mean cell volume $(\bigcirc)$, and the total cell volume $(\square)$ are shown.

product of cell count $\mathrm{ml}^{-1}$ and mean cell volume) relatively constant; this is a useful measure of biomass (Williams, 1971). Inspection of the size distributions showed that the changes in mean cell volume were due to a decrease in the number of cells occupying the large size classes with a concomitant increase in the frequency of small cells, especially those less than $10 \mu \mathrm{m}^{3}$, of which there were very few prior to sonication. This, coupled with the increase in cell numbers, indicates that large particles were being broken into smaller particles, but this was not due to the general disintegration of the cells, for the following reasons. (1) The viability of the cell suspension remained constant. Samples removed during the sonication of a suspension of $S$. halophilus were serially diluted, plated out on solidified $[1.5 \%(\mathrm{w} / \mathrm{v})$ agar $]$ defined medium and the numbers of colonies counted after incubation at $25^{\circ} \mathrm{C}$ for $48 \mathrm{~h}$. The viable counts showed no significant change with length of sonication, and the values obtained were comparable with the initial total count obtained with the Coulter counter. (2) Very little intracellular material (ATP, protein and $260 \mathrm{~nm}$-absorbing substances) was found in the suspending buffer. This was in contrast to the effects of treatment in a French press or of shaking the suspension with glass beads (using the method of Lang et al., 1977), when large amounts of these materials were released. French press treatment was ineffective below about $32 \mathrm{MPa}$, but above this threshold value the quantities of released cellular components increased dramatically (A. Ajmeri, R. K. Poole \& I. Salmon, unpublished observations). (3) Prolonged sonication caused little change in cell numbers or mean cell volumes.

These observations, which were confirmed by phase-contrast microscopy (results not shown), indicate that the changes in cell numbers and size distributions were caused by the selective disruption of the connecting sterigmata between mother and daughter cells with the consequent separation of the two cell types.

\section{Effect of sonication on cells of different ages in the cell cycle}

Cells at different stages of the cell cycle, obtained by isopycnic fractionation of an exponentially growing culture (Salmon \& Poole, 1983a) were sonicated for $60 \mathrm{~s}$. The effects of this treatment on the volume distributions of these cells are shown in Fig. 2. The size distributions of the exponential culture (Fig. $2 a$ ) and of six of the fractions (Fig. $2 b$ to $g$ ) are presented on the left; the corresponding distributions on the right are of the fractions after sonication. In general, sonication produced new classes of smaller particles; these new 

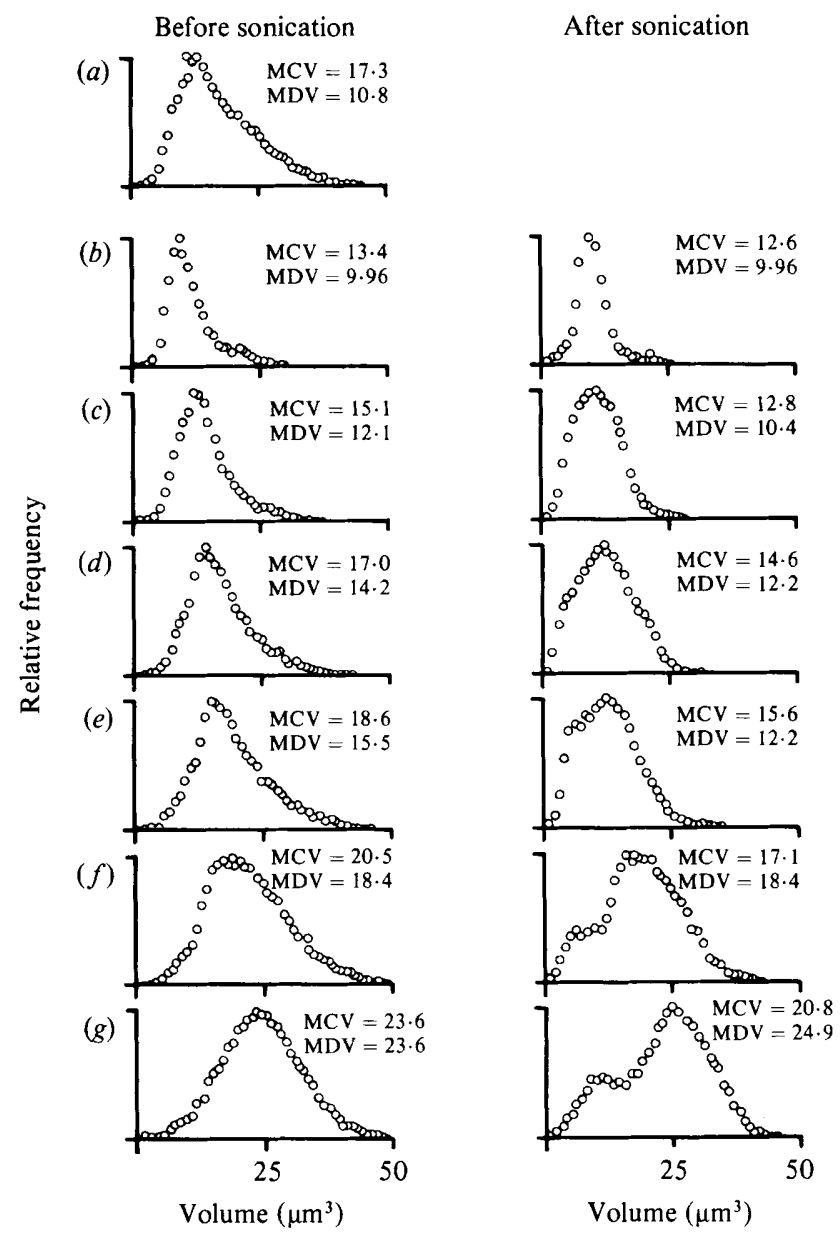

Fig. 2. The effect of ultrasonication on the size distribution of fractions obtained in an isopycnic separation of $S$. halophilus. The distributions on the left of the Figure are of $(a)$ the original exponentially growing population and $(b$ to $g$ ) fractions from the separation; those on the right are of the corresponding fractions after sonication for $60 \mathrm{~s}$. The mean cell volume (MCV) and modal cell volume (MDV) of each distribution are given in $\mu^{3}$. For simplicity, only alternate data points in the size distributions are plotted.

populations were especially easily discernible in those fractions which originally contained large cells (Fig. $2 f, g$ ). In fractions that initially contained smaller cells (Fig. $2 d, e$ ) the presence of the new populations of particles were only suggested by shoulders on the size distributions. In the fractions containing the smallest cells (Fig. $2 b, c$ ) no new populations were observed, though in Fig. $2(c)$ there was a definite increase in the frequency of particles at smaller volumes, and in Fig. $2(b)$ the population of cells around $18 \mu \mathrm{m}^{3}$ was lost on sonication.

The new populations of particles are interpreted as being immature daughters released by the action of sonication. Estimates of the size of these buds may be made by inspection of the size distributions of the sonicated fractions, and are about $5 \mu \mathrm{m}^{3}$ in Fig. $2(d)$, about $6 \mu \mathrm{m}^{3}$ in Fig. $2(e)$, about $7 \mu \mathrm{m}^{3}$ in Fig. $2(f)$, and about $11 \mu \mathrm{m}^{3}$ in Fig. $2(\mathrm{~g})$.

The effect of age in the cell cycle on the susceptibility of cells to disruption of their sterigmata was tested in an experiment similar to that described above. Cell numbers in each fraction were determined before and after sonication. A plot of increase in number against mean cell volume of the unsonicated fraction is shown in Fig. 3. This shows increasing ease of disruption with cell age (as measured by the mean cell volume). Scatter was great in these experiments, allowing only 


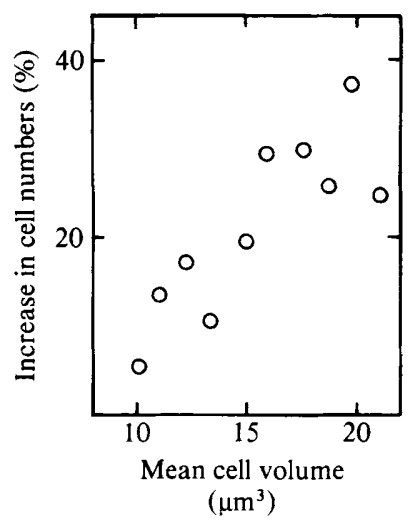

Fig. 3. The percentage increase in cell numbers, in samples from an isopycnic fractionation of $S$. halophilus, on ultrasonication for $60 \mathrm{~s}$, plotted against the mean cell volume of the fraction (a measure of cell age) prior to sonication.

a general trend to be established. Scanning electron microscopy (results not shown) confirmed the increasing sizes of buds in mother-daughter pairs in successive unsonicated fractions from a cell fractionation.

\section{Mother-daughter fractionations}

Fractions containing cells at different stages in the cell cycle were obtained by isopycnic-zonal fractionation and split into two. One portion of each fraction was sonicated for $60 \mathrm{~s}$. The sonicated and unsonicated samples were each loaded on to sucrose gradients and centrifuged in a swing-out rotor. Cells from unsonicated samples sedimented as narrow, discrete bands. However, after sonication the cells in such fractions separated into two or more bands. For cells early in the cell cycle (Fig. $4 a$ ), or late in the cell cycle (Fig. $4 d$ ), only two discrete bands were seen, but with intermediate cell cycle stages three bands were observed (Fig. $4 b, c$ ). Each band was collected with a syringe and the cells were sized. Results for four such fractionations are shown in Fig. 4. The slowly sedimenting band of cells (fraction 1 in Fig. 4) was found to contain the smallest particles. These particles increased in size with the position in the cell cycle of the original population, ranging from a mean cell volume of $4.26 \mu \mathrm{m}^{3}$ (from an original population of $13.0 \mu \mathrm{m}^{3}$, Fig. $4 a$ ) to $10.5 \mu \mathrm{m}^{3}$ (from an original population of $20.5 \mu \mathrm{m}^{3}$, Fig. $4 d$ ). These fractions were assumed to be isolated immature buds, being smaller than, or nearly equivalent to, the neonatal cell size of $9.5 \mu^{3}$ (Salmon \& Poole, 1983a). The next group of cell bands (fraction 2 in Fig. 4) were found to contain cells of essentially the same size (roughly $9.5 \mu \mathrm{m}^{3}$ ) and were taken to represent unbudded mother cells (i.e. mother cells from which the daughter cells had been removed). In separations of particles derived from cells at the end of the cycle, the buds are mature and consequently sediment with mother cells; thus, fraction 1 in Fig. $4 d$ contains both mother cells and buds. The fastest sedimenting band (fraction 3 in Fig. 4) contained mother-daughter pairs which had not been disrupted by sonication. This population should correspond therefore to that prior to sonication, and a good correlation was indeed observed between these two populations (Fig. $4 b, c, d$ ). Early in the cell cycle, the difference in size between mother-daughter pairs and mother cells only was insufficient to separate these two classes (Fig. 4a).

The relationship between the size of the immature buds isolated and the position in the cell cycle (as determined by mean cell volume of the original fraction) is shown in Fig. 5, which contains the data from several experiments.

\section{Spatial distribution of membrane-bound enzymes during the cell cycle of $S$. halophilus}

Fractions containing cells at different stages in the cell cycle were split into two samples, one of which was sonicated to disrupt the sterigmata, and the released immature buds were then 


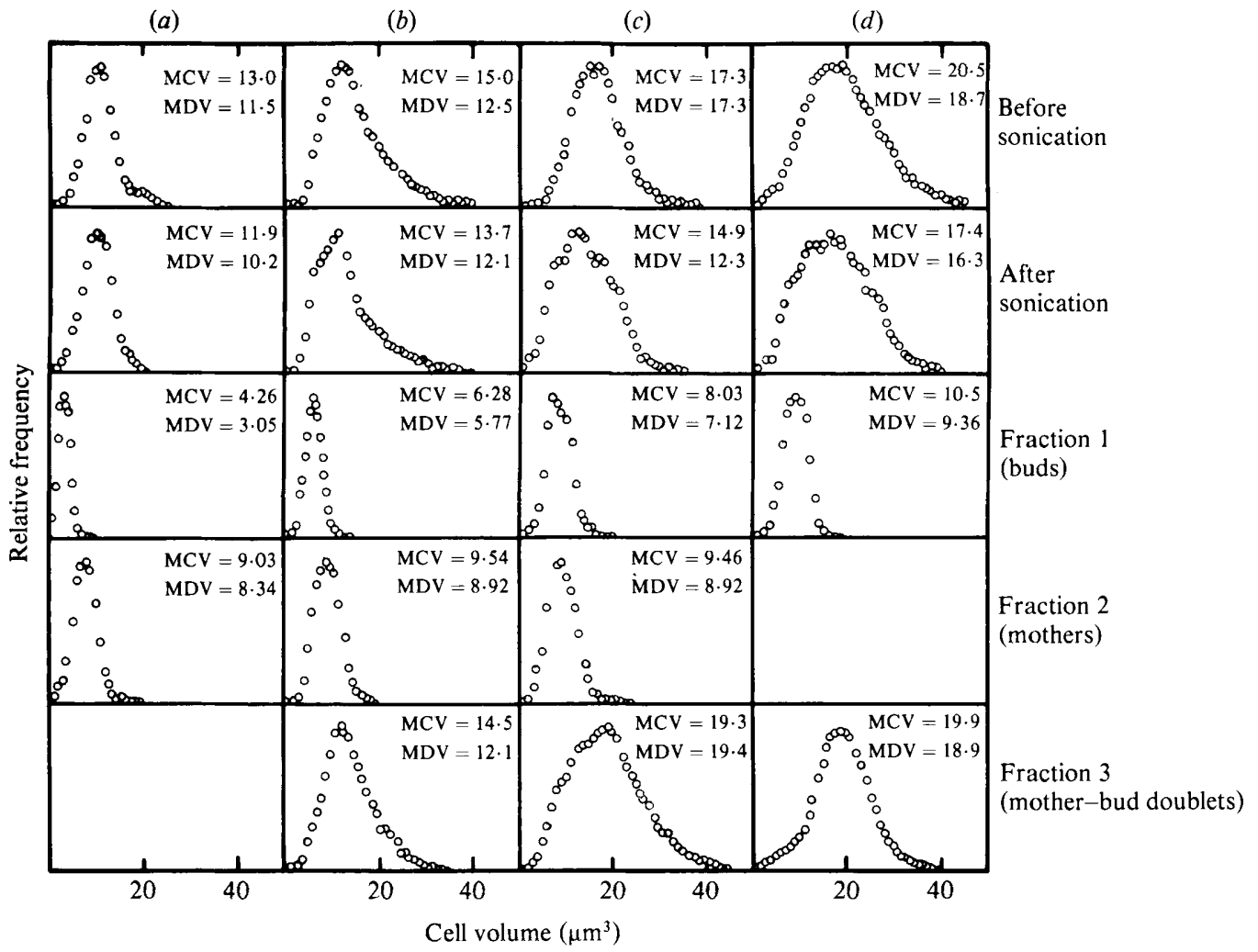

Fig. 4. The isolation of immature daughter buds at different stages in the cell cycle of $S$. halophilus. Fractions representing cells at different stages of the cell cycle were obtained by an isopycnic-zonal separation of an exponentially growing culture of $S$. halophilus. A portion of each fraction was sonicated, loaded on to a sucrose gradient and centrifuged as described below. After centrifugation, the suspension was separated into two or three bands which were removed and sized. Separations $(a),(b)$ and $(c)$ were of fractions with original mean cell volumes of $13.0,15.0$ and $17.3 \mu \mathrm{m}^{3}$, respectively, and were obtained after centrifuging at 2000 r.p.m. for $4 \min \left(650 \mathrm{~g}, r_{\mathrm{av}}, 14.5 \mathrm{~cm}\right)$. Separation $(d)$ was of cells with an original mean volume of $20.5 \mu \mathrm{m}^{3}$ and was centrifuged for $4 \mathrm{~min}$ at 1500 r.p.m. $\left(360 \mathrm{~g}, r_{\mathrm{av}}\right.$. $14.5 \mathrm{~cm}$ ). The first row of distributions in the Figure is of the original samples obtained from an isopycnic fractionation, and the second is of the same fractions, but after sonication. The next three rows of distributions are of the bands of cells removed from the rate separation of the sonicated samples, and correspond to immature daughter cells, mother cells, and mother-daughter doublets, respectively. The mean cell volume (MCV) and modal cell volume (MDV) for each distribution are given in $\mu \mathrm{m}^{3}$. For simplicity, only alternate data points in the size distributions are plotted.

isolated by rate sedimentation. The activities of two mitochondrial enzymes were measured in extracts prepared from (1) the purified bud fraction and (2) the retained mother-bud doublets. Sufficient yields of the immature buds for this study could only be obtained from cells in the latter part of the cell cycle.

The total protein content of the immature buds was directly related to their mean volume (Fig. 6 ), and their protein content per unit cell volume was $87 \pm 4.4 \mathrm{fg}$ protein $\mu \mathrm{m}^{-3}$ ( \pm S.D. of six samples), which was not significantly different from that of the mother-bud doublets $\left(85 \pm 5.5 \mathrm{fg}\right.$ protein $\left.\mu \mathrm{m}^{-3}\right)$ from which they were derived.

Fig. 7 shows the patterns of activity observed for succinate dehydrogenase (Fig. $7 a$ ) and cytochrome $c$ oxidase (Fig. $7 b$ ) in cells during the cell cycle and in immature daughters isolated from cells in the latter half of the cycle. The activities in immature daughters were plotted against the mean cell volume of the fraction from which they were isolated. The enzymes showed an overall doubling in activity on a per cell basis during the cell cycle and displayed oscillatory patterns of activity that were similar to those described previously for unseparated mother-bud 


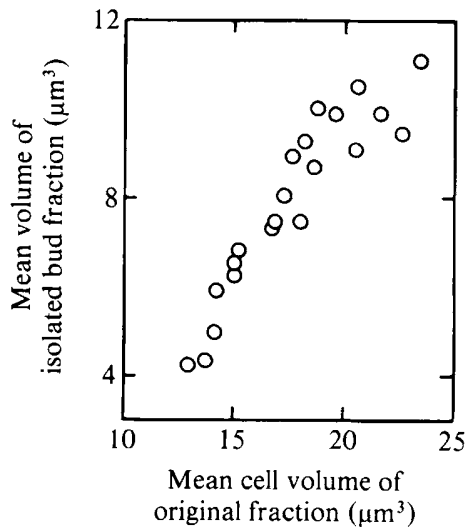

Fig. 5. The sizes of the isolated immature daughter cells at different stages in the cell cycle of $S$. halophilus. The mean volume of the mother-daughter pair (i.e. of the original fraction) was used as a measure of cell cycle age.

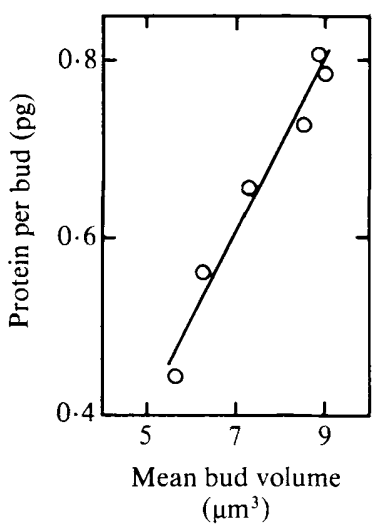

Fig. 6. The total protein content of immature buds isolated from cells of $S$. halophilus at different stages in the cell cycle. Data points are the means of four determinations.

doublets (Salmon \& Poole, 1983b). Succinate dehydrogenase displayed a single maximum in activity in cells of about $12 \mu \mathrm{m}^{3}$ (Fig. $7 a$ ), while cytochrome $c$ oxidase activity showed two maxima in cells of $13.2 \mu \mathrm{m}^{3}$ and $15.4 \mu \mathrm{m}^{3}$ (Fig. $7 \mathrm{~b}$ ). The activity per isolated daughter cell was always less than that observed in the corresponding mother-daughter pair and varied in phase with it (Fig. 7). The specific activities [amol substrate utilized $\min ^{-1}$ (pg protein) ${ }^{-1}$ ] of both enzymes in either the mother-bud doublets or the isolated immature daughters were not significantly different at any stage of the cell cycle examined (Table 1). Similar results were observed in two other experiments.

\section{DISCUSSION}

The partitioning of enzyme activity between mother and daughter cells during the cell cycle of $S$. halophilus was studied by exploiting the unusual mode of budding in this yeast. Short periods of ultrasonication produced relatively high yields of immature buds. The yield of immature buds obtained depended upon the stage in the cell cycle that the mother-bud doublet had reached; more buds could be detached from cells at the end of the cell cycle (about $40 \%$ ) than from those at the beginning (about $5 \%$ ). Similar observations were made by Galdiero (1973) on Saccharomyces cerevisiae, though he was only able to obtain yields of between $10 \%$ (for cells mid-way through the cell cycle) to $25 \%$ (for cells at the end of the cell cycle) even when employing the much more drastic measure of prolonged treatment in a Waring blender. 


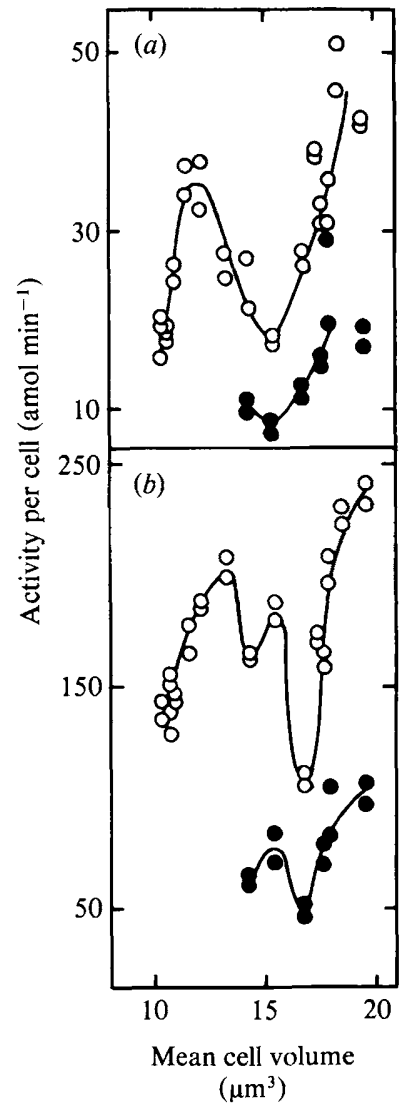

Fig. 7. Distribution of marker enzymes for the inner mitochondrial membrane between mother and bud cells during the cell cycle of $S$. halophilus. Plotted as a function of mean cell volume (and thus age in the cell cycle) are the activities per cell of $(a)$ succinate dehydrogenase and $(b)$ cytochrome $c$ oxidase in the mother-bud doublets $(O)$ and, in those fractions where the developing buds could be removed and separated, the bud fraction $(O)$.

Table 1. Specific activities of succinate dehydrogenase and cytochrome c oxidase in mother-bud doublets of $S$. halophilus at different stages in the cell cycle and in the immature buds isolated from these cells

Mother-bud doublets

\begin{tabular}{|c|c|c|}
\hline \multirow{2}{*}{$\begin{array}{l}\text { Mean cell } \\
\text { volume } \\
\left(\mu \mathrm{m}^{3}\right)\end{array}$} & \multicolumn{2}{|c|}{ Specific activity* } \\
\hline & $\begin{array}{c}\text { Succinate } \\
\text { dehydrogenase }\end{array}$ & $\begin{array}{c}\text { Cytochrome } c \\
\text { oxidase }\end{array}$ \\
\hline $14 \cdot 3$ & $20 \cdot 3$ & 138 \\
\hline $15 \cdot 4$ & $14 \cdot 6$ & 150 \\
\hline $16 \cdot 7$ & $19 \cdot 5$ & 80 \\
\hline $17 \cdot 6$ & $20 \cdot 2$ & 103 \\
\hline $17 \cdot 9$ & $21 \cdot 7$ & 133 \\
\hline $19 \cdot 5$ & $22 \cdot 8$ & 128 \\
\hline
\end{tabular}

Isolated immature buds

\begin{tabular}{|c|c|c|}
\hline \multirow{2}{*}{$\begin{array}{l}\text { Mean cell } \\
\text { volume } \\
\left(\mu \mathrm{m}^{3}\right)\end{array}$} & \multicolumn{2}{|c|}{ Specific activity* } \\
\hline & $\begin{array}{c}\text { Succinate } \\
\text { dehydrogenase }\end{array}$ & $\begin{array}{c}\text { Cytochrome } c \\
\text { oxidase }\end{array}$ \\
\hline $5 \cdot 61$ & $22 \cdot 9$ & 142 \\
\hline $6 \cdot 24$ & $14 \cdot 1$ & 138 \\
\hline $7 \cdot 31$ & $11 \cdot 1$ & 76 \\
\hline $8 \cdot 54$ & $21 \cdot 1$ & 104 \\
\hline $9 \cdot 01$ & $31 \cdot 4$ & 120 \\
\hline 8.89 & $22 \cdot 3$ & 127 \\
\hline
\end{tabular}

* In amol substrate utilized $\min ^{-1}$ (pg protein $)^{-1}$. 
High-resolution rate separations of the suspensions containing mixtures of daughters, mothers and mother-daughter pairs were obtained. In Fig. 4(c) for example, a clear separation of particles of mean volume $8.03 \mu \mathrm{m}^{3}$ and mean volume $9.46 \mu \mathrm{m}^{3}$ was obtained, suggesting a favourable density difference, as well as a size difference, between the classes of particles. Experiments in which such suspensions were fractionated by equilibrium centrifugation (results not shown) confirmed this. Daughters and mother cells early in the cell cycle were of approximately the same density, but later the buds were less dense than the mother cells. However, rate sedimentations were always employed for these fractionations since the resolution available was superior and they were quicker to perform. All methods of cell cycle analysis, however, suffer from lack of resolution (for a discussion, see Salmon \& Poole, 1983b).

Buds smaller than about $4 \mu \mathrm{m}^{3}$ were not isolated, possibly because they were 'lost' in the sucrose gradient; the small yields of these buds would make them difficult to observe in the gradients. This limited the examination of enzyme distributions to the latter half of the cell cycle. In this portion of the cycle, the specific activities of the mitochondrial enzymes succinate dehydrogenase and cytochrome $c$ oxidase found in the isolated buds were equivalent to, and varied in phase with, those observed in the mother-daughter pairs. We have shown elsewhere that for cytochrome $c$ oxidase at least, enzyme activity is a measure of actual enzyme amount (Salmon \& Poole, 1983b). These results indicate that the two enzymes (and by implication mitochondria) are uniformly distributed between mother and daughter cells during the latter half of the cell cycle and are subject to the same control processes, whatever their location.

As discussed in the previous paper (Salmon \& Poole, 1983b), the inevitable heterogeneity of the fractions with respect to cell size and age implies that oscillations in the single mothers and buds must be greater than those shown in Fig. 7.

The results are consistent with those of Galdiero (1973) who demonstrated that total protein and lipids were equally partitioned between mother and daughter cells during the cell cycle of Sacch. cerevisiae, and with those of Stevens (1977) who, in an elegant electron microscopic study, showed that mitochondria invaded the buds of Sacch. cerevisiae very early in the cycle. It is not known whether this segregation of mitochondria is attained by a purely random process or if some regulatory mechanism operates.

I.S. held an SERC Research Studentship during the course of this work. The BXIV zonal rotor was purchased with funds from the University of London Central Research Fund. We thank Professor J. M. Mitchison for helpful advice and constructive comments.

\section{REFERENCES}

Farkas, V., Kovarik, J., Kosinova, A. \& Bauer, S. (1974). Autoradiographic study of mannan incorporation into the growing cell walls of Saccharomyces cerevisiae. Journal of Bacteriology 117, 265-269.

Fell, J. W. (1966). Sterigmatomyces, a new fungal genus from marine areas. Antonie van Leeuwenhoek 32, 99-104.

FIELD, C. \& SCHEKMAN, R. (1980). Localized secretion of acid phosphatase reflects the pattern of cell surface growth in Saccharomyces cerevisiae. Journal of Cell Biology 86, 123-128.

GaldiERo, F. (1973). The growth of cell membranes during synchronized cell division of Saccharomyces cerevisiae. Experientia 29, 496-497.

JoHnson, B. F. (1968). Lysis of yeast cell walls induced by 2-deoxyglucose at their sites of glucan synthesis. Journal of Bacteriology 95, 1169-1172.

Johnson, B. F. \& Gibson, E. J. (1966). Autoradiographic analysis of regional cell wall growth of yeasts. III. Saccharomyces cerevisiae. Experimental Cell Research 41, 580-591.
Lang, B., Burger, G., Doxiadis, I., Thomas, D. Y., Bandlow, W. \& Kaudewitz, F. (1977). A simple method for the large-scale preparation of mitochondria from microorganisms. Analytical Biochemistry 77, 110-121.

Lloyd, D., POOLE, R. K. \& Edwards, S. W. (1982). The Cell Division Cycle: Temporal Organization and Control of Cellular Growth and Reproduction. London: Academic Press.

Salmon, I. \& Poole, R. K. (1980a). Spatial distribution of two membrane-bound enzymes during the cell cycle of Sterigmatomyces halophilus. Society for General Microbiology Quarterly 8, 30.

SALMON, I. \& PoOLE, R. K. $(1980 b)$. The mitochondrial cytochromes of an unusual budding yeast, Sterigmatomyces halophilus: spectral characterization exploiting fourth-order finite difference analysis. Journal of General Microbiology 117, 315-326.

Salmon, I. \& Poole, R. K. (1983a). The cell cycle of the budding yeast Sterigmatomyces halophilus: cul- 
ture fractionation by zonal centrifugation and the accumulation of DNA, RNA and protein. Journal of General Microbiology 129, 2129-2141.

Salmon, I. \& PoOle, R. K. (1983b). The cell cycle of the budding yeast Sterigmatomyces halophilus: oscillations in the amounts and activities of the terminal components of the respiratory chain. Journal of General Microbiology 129, 2143-2152.

SkUTELSKY, E. \& BAYER, E. A. (1979). The ultrastructural delineation of cell growth and division processes using the avidin-biotin complex. Experimental Cell Research 121, 331-336.
Stevens, B. J. (1977). Variation in number and volume of the mitochondria in yeast according to growth conditions. A study based on serial sectioning and computer graphics reconstruction. Biologie cellulaire 28, 37-56.

WhItTEnBURY, R. \& Dow, C. S. (1977). Morphogenesis and differentiation in Rhodomicrobium vannielii and other budding and prosthecate bacteria. Bacteriological Reviews 41, 754-808.

Williams, F. M. (1971). Dynamics of microbial populations. In Systems Analysis and Simulation in Ecology, vol. 1, pp. 197-267. Edited by B. C. Patten. New York and London: Academic Press. 